\title{
Erratum to: Effect of Cooling Rate on the Dendrite Coherency Point During Solidification of Al2024 Alloy
}

M.H. GHONCHEH and S.G. SHABESTARI

DOI: $10.1007 / \mathrm{s} 11661-017-4262-\mathrm{z}$

(C) The Minerals, Metals \& Materials Society and ASM International 2017

Erratum to: METALLURGICAL AND MATERIALS

TRANSACTIONS A,

VOLUME 46A,

NUMBER 3, MARCH 2015,

pp. 1287-1299

DOI $10.1007 / \mathbf{s 1 1 6 6 1 - 0 1 4 - 2 6 9 7 - z}$

IN the first paragraph of the Experimental Procedure section on page $1288,477 \mathrm{~K} \pm 78 \mathrm{~K}\left(750{ }^{\circ} \mathrm{C} \pm 5^{\circ} \mathrm{C}\right)$ is incorrect. The correct temperature is $1023 \mathrm{~K} \pm 5 \mathrm{~K}$ $\left(750{ }^{\circ} \mathrm{C} \pm 5^{\circ} \mathrm{C}\right)$.

M.H. GHONCHEH, M.Sc. Graduate, and S.G. SHABESTARI, Professor, are with the Center of Excellence for High Strength Alloys Technology (CEHSAT), School of Metallurgy and Materials Engineering, Iran University of Science and Technology (IUST), 16846-13114 Narmak, Tehran, Iran. Contact e-mail: shabestari@iust.ac.ir

The online version of the original article can be found under doi: 10.1007/s11661-014-2697-z.

Article published online July 28, 2017 